\title{
Pengaruh Human Relation, Lingkungan Kerja, Budaya Organisasi Terhadap Kinerja Karyawan Dengan Komitmen Organisasi Sebagai Variabel Intervening Pada Dinas Pendidikan Provinsi Sumatera Barat
}

\author{
Chintya Ones Charli \\ Universitas Putra Indonesia YPTK Padang, Indonesia \\ chintyaonescharli@upiyptk.ac.id
}

\begin{abstract}
Abstrak
Penelitian ini bertujuan Untuk mengetahui dan menganalisa pengaruh human relation, lingkungan kerja dan budaya organisasi terhadap kinerja karyawan dangan Komitmen Organisasi sebagai variabel Intervening. Populasi dalam penelitian ini sebanyak 667 karyawan dan diambil sampel dengan mengunakan rumus Slovin maka didapati sampel yang akan diteliti dalam penelitian ini sebanyak 87 orang pada karyawan Dinas Pendidikan Provinsi Sumatera Barat. Analisis data yang dilakukan adalah dengan menggunakan analisis regresi dan path analysis mengunakan SPSS 21 sebagai alat analisis data.

Hasil penelitian menunjukan bahwa terdapat pengaruh antara human relation terhadap kinerja karyawan, lingkungan kerja berpengaruh terhadap kinerja karyawan dan budaya organisasi berpengaruh terhadap Kinerja Karyawan pada Dinas Pendidikan Provinsi Sumatera Barat. Serta terdapat (a). Pengaruh secara langsung antara human relation terhadap kinerja karyawan dengan komitmen organisasi sebagai variabel intervening, (b). Terdapat pengaruh langsung antara lingkungan kerja terhadap kinerja karyawan dengan komitmen organisasi sebagai variabel intervening dan, (c). Terdapat pengaruh langsung antara budaya organisasi terhadap kinerja karyawan dengan komitmen organisasi sebagai variabel intervenig. Hal ini menunjukan bahwa pentingnya human relation, lingkungan kerja, budaya organisasi dan didukung oleh komitmen organisasi dalam meningkatkan kinerja karyawan pada Dinas Pendidikan Provinsi Sumatera Barat.
\end{abstract}

Kata Kunci :Human relation, lingkungan kerja, budaya organisasi, kinerja dan Komitmen Organisasi

\section{Pendahuluan}

Di dalam kehidupan sehari-hari dimana pun manusia berada, dibutuhkan peraturan-peraturan dan ketentuan yang mengatur dan membatasi setiap kegiatan dan perilakunya. Hal ini membuktikan bahwa manusia sebagai makhluk sosial mampu mengendalikan setiap tindakan ataupun perbuatan berdasarkan peraturan atau ketentuan yang telah dibuat. Dimensi pokok manusia adalah perlakuan kontribusi terhadapnya yang pada gilirannya akan menentukan kualitas dan kapabilitas hidupnya. Jadi pengertian Manajemen Sumber Daya Manusia (MSDM) merupakan suatu ilmu atau cara bagaimana mengatur hubungan dan peranan sumber daya (tenga kerja) yang dimiliki oleh individu secara efisien dan efektif serta dapat digunakan secara maksimal sehingga tercapai tujuan (goal). Bersama perusahaan, karyawan dan masyarakat menjadi maksimal. MSDM di dasari pada suatu konsep bahwa setiap karyawan adalah manusia bukan mesin dan bukan semata menjadi sumber daya bisnis. MSDM menggabungkan beberapa bidang ilmu seperti psikologi, sosiologi, dan lain-lain.

Maka dapat diketahui bahwa untuk mencapai kinerja karyawan yang baik maka di perlukan human relation yang baik, lingkungan kerja yang baik dan nyaman, budaya organisasi serta komitmen organisasi untuk mencapai hasil yang optimal pada kinerja karyawan, hal ini juga terjadi pada Dinas Pendidikan Provinsi Sumatera Barat, tempat dimana penelitian ini akan dilaksanakan.

Pemerintah Kota Padang senantiasa berusaha, dengan berbagai metode meningkatkan kualitas pendidikan, tidak hanya peningkatan ilmu pengetahuan dan teknologi tapi juga peningkatan keimanan dan ketaqwaan pada Tuhan Yang Maha Esa. Hal ini sejalan dengan rencana strategis program Pendidikan Nasional, yang meliputi: 1) peningkatan akses pendidikan, kompetensi dan daya saing bangsa, 2) peningkatan mutu dan kualitas pendidikan serta 3) peningkatan manajemen dan pelayanan pendidikan yang transparan, akuntabel dan good governance. Oleh karena itu dibutuhkan 
tenaga - tenaga profesional untuk meimplementasikan gagasan tersebut. Dengan memperhatikan human relationyang baik, lingkungan kerja yang baik dan nyaman, budaya organisasi serta komitmen organisasi untuk mencapai hasil yang optimal pada kinerja karyawan.

Namun hal itu masih menjadi kendala bagi Dinas Pendidikan kota Padang, terlihat dari kajian rekapitulasi daftar absensi karyawan di Dinas Pendidikan Provinsi Sumatera Barat dalam bentuk table mulai dari bulan januari 2018 sampai dengan bulan oktober 2018, sebagai berikut :

Table 1.1

Rekapitulasi Absensi Karyawan Dinas Pendidikan Provinsi Sumatra Barat Pada Bulan Januari 2018- Oktober 2018

\begin{tabular}{ccccccc}
\hline Bulan & $\begin{array}{c}\text { Jumlah } \\
\text { karyawan }\end{array}$ & $\begin{array}{c}\text { Hadir } \\
\text { tepat } \\
\text { waktu }\end{array}$ & & & Keterangan & \\
\cline { 4 - 6 } & & & Izin & Sakit & Cuti & Total \\
\hline Januari & 87 & 60 & 3 & 5 & 6 & 14 \\
Februari & 87 & 62 & 8 & 3 & 4 & 15 \\
Maret & 87 & 61 & 5 & 4 & 3 & 12 \\
April & 87 & 62 & 3 & 2 & 9 & 14 \\
Mei & 87 & 63 & 9 & 2 & 5 & 16 \\
Juni & 87 & 61 & 7 & 6 & 7 & 20 \\
Juli & 87 & 61 & 3 & 5 & 3 & 11 \\
Agustus & 87 & 63 & 8 & 2 & 2 & 12 \\
September & 87 & 64 & 5 & 2 & 4 & 11 \\
\hline
\end{tabular}

(Sumber: Dinas Pendidikan Provinsi Sumatra Barat)

Dari gambar 1.1 di atas dapat dilihat bahwa daftar kehadiran karyawan Dinas Pendidkan Provinsi Sumatra Barat selalu berfluktuasi (naik turun) pada Dinas Pendidkan Provinsi Sumatra Barat pada bulan Januari 2018 sampai bulan Oktober 2018. Alasan ketidakhadiran karyawan berbeda-beda, ketika tingkat kehadiran karyawan rendah maka akan berdampak pada menurunya tingkat kinerja karyawan pada Dinas Pendidikan Provinsi Sumatera Barat. Yang dimana terdapat beberapa faktor yang mempengaruhi kinerja karyawan. Diantaranya faktor internal antara lain : disiplin kerja, kepuasan kerja, dan motivasi karyawan. Faktor eksternal meliputi : gaya kepemimpinan, human relation, lingkungan kerja, kompensasi dan sistem manajemen yang terdapat di perusahaan tersebut. Faktor-faktor tersebut hendaknya perlu diperhatikan oleh pimpinan sehingga kinerja karyawan dalam perusahaan dapat optimal.

Penelitian yang dilakukan Supriatna (2017), dengan hasil penelitian menunjukan bahwa adanya pengaruh human relation terhadap kinerja karyawan dengan komitmen organisasi sebagai variabel intervening. Hal ini membuktikan bahwa human relation (hubungan antar manusia) di dalam perusahaan merupakan faktor yang harus diperhatikan sepenuhnya oleh perusahaan, karena merupakan salah satu faktor penting dalam upaya meningkatkan kinerja karyawan dan komitmen organisasi karyawan.

Penelitian yang dilakukan oleh Sekar (2017) dengan hasil penelitian terdapat pengaruh yang signifikan lingkungan kerja terhadap kinerja karyawan dengan komitmen organisasi sebagai variabel intervening. Hal ini membuktikan bahwa dengan lingkungan kerja yang baik, suasana dan rekan kerja yang baik akan menciptakan kinerja karyawan yang optimal.

Selanjutnya penelitian yang dilakukan oleh Suryani (2016) dengan hasil penelitian menunjukan terdapat pengaruh yang signifikan antara budaya organisasi terhadap kinerja karyawan dengan komitmen organisasi sebagai variabel intervening. Hal ini menunjukan bahwa pentingnya budaya organisasi yang baik dilaksanakan didalam suatu organisasi, instansi atau perusahaan karena terbukti meningkatkan kinerja karyawan.

\section{Kerangka Pemikiran}

Berdasarkan rumusan masalah dan landasan teori diatas, dapat disimpulkan bahwa human relation (X1), lingkungan kerja (X2), dan budaya organisasi (X3) berpengaruh terhadap kinerja 
karyawan (Y) dengan komitmen organisasi sebagai variabel intervening (Z). Maka dapat disusun suatu kerangka pemikiran dalam penelitian ini, seperti yang disajikan dalam gambar 2.1 berikut ini :

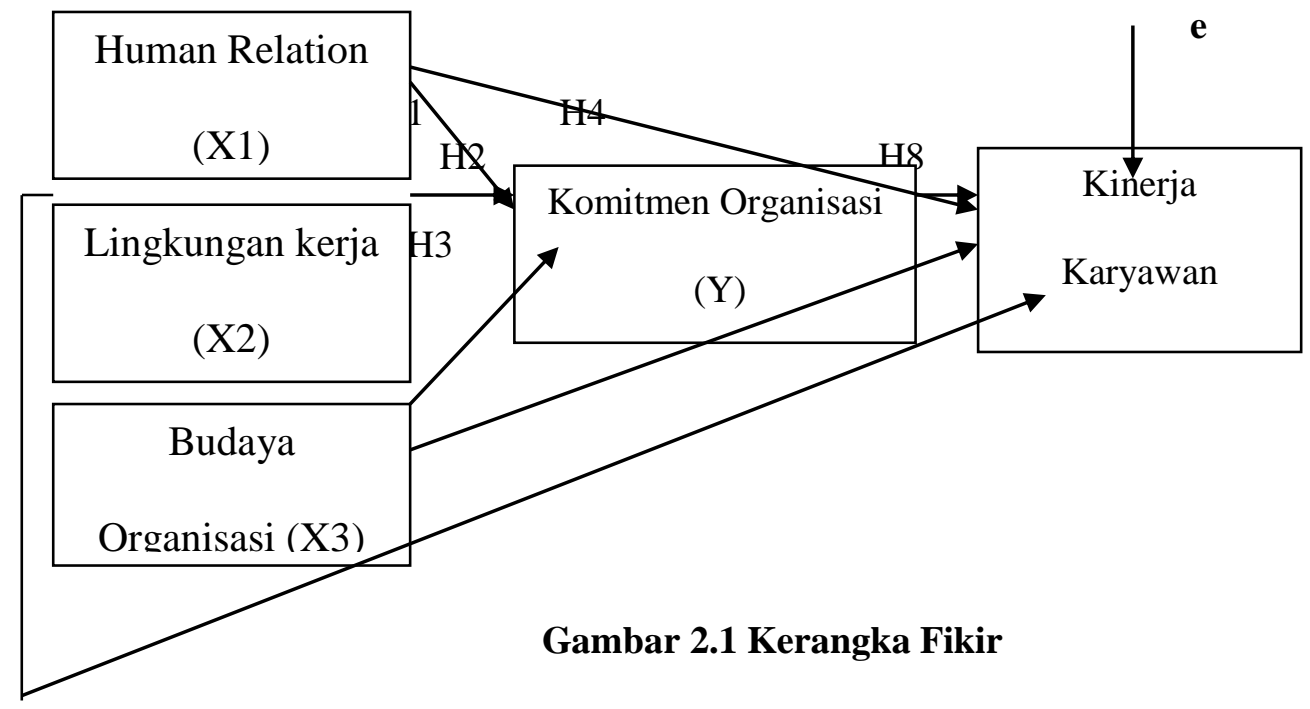

\section{Hipotesis}

Hipotesis diartikan sebagai dugaan sementara atau pendapat yang masih perlu dibuktikan kebenarannya. Adapun hipotesis pada penelitian ini adalah :

H1 : Human Relation berpengaruh terhadap Kinerja karyawan pada Dinas Pendidikan Provinsi Sumatera Barat

H2 : Lingkungan kerja berpengaruh terhadap Kinerja karyawan pada Dinas Pendidikan Provinsi Sumatera Barat

H3 : Budaya Organisasi berpengaruh terhadap Kinerja Karyawan pada Dinas Pendidikan Provinsi Sumatera Barat

H4 : Komitmen Organisasi berpengaruh terhadap Kinerja Karyawan pada Dinas Pendidikan Provinsi Sumatera Barat

H5 : Human relation berpengaruh terhadap Kinerja Karyawan dengan komitmen sebagai variabel intervening pada Dinas Pendidikan Provinsi Sumatera Barat

H6 : Lingkungan Kerja berpengaruh terhadap Kinerja Karyawan dengan komitmen sebagai variabel intervening pada Dinas Pendidikan Provinsi Sumatera Barat

H7 : Budaya Organisasi berpengaruh terhadap Kinerja Karyawan dengan komitmen sebagai variabel intervening pada Dinas Pendidikan Provinsi Sumatera Barat

\section{Metodologi Penelitian}

\section{Objek Penelitian}

Kegiatan penelitian ini dilakukan di kota Padang, pada Dinas Pendidikan Provinsi Sumatera Barat, yang beralamat pada Jl. Jend Sudirman No 52 Jati Baru. Padang Timur Kota Padang, Sumatera barat. Telp. 075131513

\section{Desain Penelitian}

Pada penelitian ini menggunakan metode kuantitatif, menurut Sugioyono (2016), metode kuantitatif adalah metode yang berlandasan pada filsafat positifisme, digunakan untuk meneliti pada populasi dan sampel tertentu, pengumpulan data menggunakan instrumen penelitian, analisis data bersifat kuantitatif/statistik dengan tujuan untuk mendapatkan informasi berupa data diri karyawan, dan hasil penelitian sesuai dengan hipotesisis yang akan diteliti. 


\section{Popupasi dan Sampel Populasi}

Menurut Sugiyono (2016) mengatakan populasi adalah wilayah generalisasi yang terdiri atas objek atau subjek yang mempunyai kualitas dan karateristik tertentu yang diterapkan oleh peneliti untuk dipelajari dan kemudian ditarik kesimpulannya. Jadi populasi bukan hanya orang, tetapi juga objek dan benda-benda alam lainnya. Populasi juga bukan sekedar jumlah yang ada pada obyek atau subyek yang dipelajari. tetapi meliputi karateristik atau sifat yang dimiliki oleh subyek atau obyek. Populasi dalam penelitian ini adalah seluruh karyawan pada instansi Dinas Pendidikan Provinsi Sumatera Barat sebanyak 667 orang karyawan.

\section{Sampel}

Sampel adalah bagian kecil dari suatu populasi atau yang mewakili populasi sekaligus menggambarkan populasi itu sendiri, Sugiyono (2016). Untuk memilih responden digunakan pengambilan sampel secara acak disebut metode sampling untuk menentukan sampel dari suatu populasi. Rumus Slovin yaitu banyaknya sampel dapat ditentukan dengan rumus sebagai berikut:

$$
\begin{aligned}
& \mathrm{n}=\frac{\mathrm{N}}{1+\mathrm{Ne}^{2}} \\
& \text { Dapat dijelaskan : } \\
& \mathrm{n}=\frac{667}{1+667(10 \%)^{2}} \\
& =86,962 \\
& =87 \\
& \text { Dimana: } \\
& \mathrm{n}=\text { ukuran sampel } \\
& \mathrm{N}=\text { Ukuran populasi yaitu jumlah karyawan Dinas Pendidikan Sumatera } \\
& \quad \text { Barat } \\
& \mathrm{e}=\text { Eror tolerance (toleransi kegagalan) yang masih dapat ditelorir (pada } \\
& \quad \text { penelitian ini digunakan 10\%) } \\
& 1=\text { konstanta }
\end{aligned}
$$

Berdasarkan rumus tersebut, maka jumlah sampel yang diambil dalam penelitian ini adalah 87 orang

\section{Defenisi Variabel \\ Human Relation}

Human relation adalah komonikasi persuasive yang dilakukan oleh seseorang kepada orang lain secara tatap muka dalam segala situasi dan dalam semua bidang kehidupan sehingga menimbulkan kebahagiaan dan kepuasan hati kedua belah pihak. Dikatakan bahwa hubungan manusiawi itu merupakan suatu komunikasi karena sifatnya yang orientasi pada perilaku (action oriented), hal ini mengandung kegiatan untuk mengubah sikap, pendapat, atau perilaku seseorang (Effendy, 2011).

\section{Lingkungan Kerja}

Lingkungan kerja adalah segala sesuatu yang ada pada lingkungan atau lingkup kerja suatu individu baik dari segi lokasi, rekan kerja, sarana dan prasarana yang dapat memenuhi seluruh kegiatan individu dalam melakukan pekerjaannya. Menurut Kasmir (2016), lingkungan kerja merupakan sarana dan prasarana atau kondisi pada sekitar lokasi tempat bekerja. Lingkungan kerja dapat berupa ruangan, layout, sarana dan prasarana, serta hubungan kerja dengan sesama rekan kerja.

\section{Budaya Organisasi}

budaya organisasi merupakan cara menganalisis, berperasaan dan bereaksi berdasarkan aturan - aturan yang ada dalam perusahaan atau yang ada pada bagian-bagian perusahaan. budaya organisasi juga merupakan sistem nilai organisasi dan akan mempengaruhi cara pekerjaan dilakukan dan cara para karyawan berperilaku. Dapat disimpulkan bahwa yang dimaksud dengan budaya organisasi dalam penelitian ini adalah sistem nilai organisasi yang dianut oleh anggota organisasi, yang kemudian mempengaruhi cara bekerja dan berperilaku dari para anggota organisasi (Robins, 2014). 


\section{Kinerja Karyawan}

Kinerja merupakan hasil kerja atau prestasi kerja yang dilakukan oleh karyawan sesuai dengan persyarat-syaratan yang sudah ditentukan. Menurut Wibowo (2014), kinerja berasal dari pengertian performance, yaitu sebagai hasil kerja atau prestasi kerja. Namun, sebenarnya kinerja mempunyai makna yang lebih luas, bukan hanya hasil kerja, tetapi termasuk bagaimana proses pekerjaan berlangsung.

\section{Komitmen Organisasi}

Komitmen organisasional bisa tumbuh disebabkan karena individu memiliki ikatan emosional terhadap perusahaan yang meliputi dukungan moral dan menerima nilai yang ada di dalam perusahaan serta tekad dari dalam diri untuk mengabdi pada perusahaan. komitmen organisasional adalah sikap yang merefleksikan loyalitas karyawan pada organisasi dan proses berkelanjutan dimana anggota organisasi mengekpresikan perhatiannya terhadap organisasi dan keberhasilan serta kemajuan yang berkelanjutan (Luthans, 2012).

\section{Analisis Regresi Linear Berganda}

Menurut Basuki \& Prawoto (2016) regresi berganda merupakan teknik statistika untuk membuat model dan menyelidiki pengaruh antara satu atau beberapa variabel bebas (independent variables) terhadap satu variabel respons (dependent variable) dengan melihat nilai Unstandardized Coefficients dengan mengunakan aplikasi SPSS ,dengan asumsi semakin tinggi atau besar nilai Beta maka semakin berpengaruh variabel bebas terhadap variabel terikat dirumuskan sebagai berikut:

$$
Y=a+b 1 X 1+b 2 X 2+b 3 X 3+e
$$

\section{UJI HIPOTESIS}

\section{Uji-t (Persial)}

Uji t dapat dilakukan hanya dengan memperhatikan hasil nilai signifikasi masing-masing variabel yang terdapat pada output hasil analisis regersi pada tabel coefficients dengan mengunakan aplikasi SPSS. jika hasil angka signifikasi lebih kecil dari $\alpha$ sebesar 5\% atau 0,05 maka dapat dinyatakan bahwa ada pengaruh yang signifikan antar variabel bebas terhadap variabel terikat. Menurut Sugiyono (2014), jumlah data (t-test) dari tabel coeffiecient dibandingkan dengan t-tabel dengan menggunakan tingkat kesalahan 0,05 .

\section{Uji-F (Simultan)}

Uji f digunakan menguji signifikasi koefisien regresi secara keseluruhan dan pengaruh variable bebas secara bersama-sama. Menurut Sugiyono (2016), F hasil perhitungan ini dibandingkan dengan yang diperoleh dengan menggunakan tingkat resiko atau signifikan level 5\% atau dengan degree freedom $=\mathrm{k}(\mathrm{n}-\mathrm{k}-1)$.

\section{Koefisien Determinasi $\left(\mathbf{R}^{2}\right)$}

Menurut Riduwan (2017) Untuk menyatakan besar kecilnya sumbangan variabel X terhadap $\mathrm{Y}$ dapat ditentukan dengan rumus koefisien diterminan. Koefisien determinan adalah kuadrat dari koefisien PPM yang dikalikan dengan $100 \%$. Dilakukan untuk mengetahui seberapa besar variabel X mempunyai kontribusi atau ikut menentukan variabel Y. Derajad koefisien determinasi dicari dengan menggunakan rumus :

$$
\mathrm{KD}=\mathrm{r}^{2} \times 100 \%
$$

\section{Analisis Regresi dengan variabel intervening ( Path Analisis )}

Analisis regresi dengan menggunakan variabel intervening diuji dengan menggunakan Analisis Jalur (Path Analysis). Analisis jalur merupakan perluasan dari analisis regresi untuk menaksir hubungan kausalitas antar variabel (model kausal) yang telah ditetapkan sebelumnya berdasar teori.

Persamaan 1 :

$\mathrm{Y} 1=\beta 1 \mathrm{X} 1+\beta 2 \mathrm{X} 2+\mathrm{e}$

Persamaan 2:

$\mathrm{Y} 2=\beta 1 \mathrm{X} 1+\beta 2 \mathrm{X} 2+\beta 3 \mathrm{X} 3+\mathrm{e}$ 


\section{Hasil dan Pembahasan Hasil Uji Regresi Persamaan 1}

Tabel 2 : Coefficients

\begin{tabular}{|c|c|c|c|c|c|}
\hline \multirow[b]{2}{*}{ Model } & \multicolumn{2}{|c|}{$\begin{array}{c}\text { Unstandardized } \\
\text { Coefficients }\end{array}$} & \multirow{2}{*}{$\begin{array}{c}\begin{array}{c}\text { Standardized } \\
\text { Coefficients }\end{array} \\
\text { Beta } \\
\end{array}$} & \multirow[b]{2}{*}{$\mathbf{T}$} & \multirow[b]{2}{*}{ Sig. } \\
\hline & B & Std. Error & & & \\
\hline 1 (Constant) & 2,353 & 6,349 & & 371 &, 712 \\
\hline Human Relation & ,417 &, 165 & ,340 & 2,530 & 013 \\
\hline Lingkungan Kerja & ,378 &, 115 & ,316 & 3,285 & 001 \\
\hline Budaya Organisasi &, 053 & , 126 &, 056 &, 420 & ,676 \\
\hline
\end{tabular}

Sumber : SPSS 21.0 dan data primer yang diolah

Berdasarkan table diatas maka dapat dilihat persamaan regresinya yaitu :

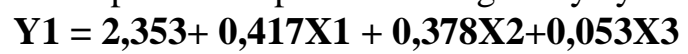

Dari Tabel diatas dapat dilihat bahwa terdapat pengaruh signifikan antara human relation dan lingkungan kerja terhadap komitmen organisasi dan tidak terdapat pengaruh yang signifikan antara budaya organisasi terhadap komitmen organisasi dikarenakan nilai sig. Lebih kecil dibandingkan dengan 0,05 skala alpha.

Tabel 3 : Model Summary

\begin{tabular}{llccr}
\hline Model & R & R Square & $\begin{array}{c}\text { Adjusted R } \\
\text { Square }\end{array}$ & \multicolumn{2}{c}{$\begin{array}{c}\text { Std. Error of the } \\
\text { Estimate }\end{array}$} \\
\hline 1 & $0,484^{\text {a }}$ & 0,234 & 0,206 & 7,734 \\
\hline \multicolumn{2}{l}{ Sumber : SPSS 21.0 dan data primer yang diolah } & &
\end{tabular}

Berdasarkan tabel di atas diperoleh angka Adjusted RSquaresebesar 0,206atau 20,6\%, hal ini menunjukkan bahwa persentase sumbangan variabel independenHuman relation, lingkungan kerja dan budaya organisasi terhadap variabel dependen komitmen organisasi rendah. diduga jal ini disebabkan oleh pengaruh variabel lain yang tidak diteliti pada penelitian ini seperti, pembinaan, pengembangan dan pemberdayaan karyawan yang masih kurang diberikan.

\section{Hasil Uji Regresi Persamaan II}

Tabel 4 : Coefficients

\begin{tabular}{|c|c|c|c|c|c|}
\hline \multirow[b]{2}{*}{ Model } & \multicolumn{2}{|c|}{$\begin{array}{c}\text { Unstandardized } \\
\text { Coefficients }\end{array}$} & \multirow{2}{*}{$\begin{array}{c}\begin{array}{c}\text { Standardized } \\
\text { Coefficients }\end{array} \\
\text { Beta }\end{array}$} & \multirow[b]{2}{*}{$\mathbf{T}$} & \multirow[b]{2}{*}{ Sig. } \\
\hline & B & Std. Error & & & \\
\hline 1 (Constant) & 7,887 & 2,771 & & 2,847 & 006 \\
\hline Human Relation & ,482 &, 075 &, 516 & 6,453 & 000 \\
\hline Lingkungan Kerja & 159 & 053 & ,174 & 2,972 & ,004 \\
\hline Budaya Organisasi & 019 & 055 & 026 & ,339 &, 735 \\
\hline Komitmen Organisasi & 352 & 048 & 463 & 7,362 &, 000 \\
\hline
\end{tabular}

Sumber : SPSS 21.0 dan data primer yang diolah

Berdasarkan tablediatas maka dapat dilihat persamaan regresinya yaitu :

$$
\mathrm{Y} 2=7,887+0,482 \mathrm{X} 1+0,159 \mathrm{X} 2+0,019 \times 3+0,352 \mathrm{Z}
$$

Dari Tabel diatas dapat dilihat bahwa terdapat pengaruh signifikan antara human relation, lingkungan kerja dan komitmen organisasi terhadap kinerja karyawan dan tidak terdapat pengaruh yang signifikan antara budaya organisasi terhadap kinerja karyawan dikarenakan nilai sig. Lebih kecil dibandingkan dengan 0,05 skala alpha. 
Tabel 5 : Model Summary

\begin{tabular}{lcccc}
\hline Model & R & R Square & $\begin{array}{c}\text { Adjusted R } \\
\text { Square }\end{array}$ & \multicolumn{2}{c}{$\begin{array}{c}\text { Std. Error of the } \\
\text { Estimate }\end{array}$} \\
\hline 1 & $0,867^{\text {a }}$ & 0,751 & 0,739 & 3,373 \\
\hline \multicolumn{4}{c}{ Sumber : SPSS 21.0 dan data primer yang diolah } \\
Berdasarkan tabel di atas diperoleh angka Adjusted RSquaresebesar 0,751 atau $75,1 \%$, hal ini \\
menunjukkan bahwa persentase sumbangan variabel independenHuman relation, lingkungan kerja, \\
budaya organisasi dan komitmen organisasiterhadap variabel dependen kinerja karyawankuat.
\end{tabular}

\section{Path Analysis}

Untuk menguji pengaruh variabel intervening digunakan metode analisis jalur (path Analysis). Analisis jalur merupakan perluasan dari analisis linier berganda.

Gambar 2

Diagram Jalur (Path Analysis)

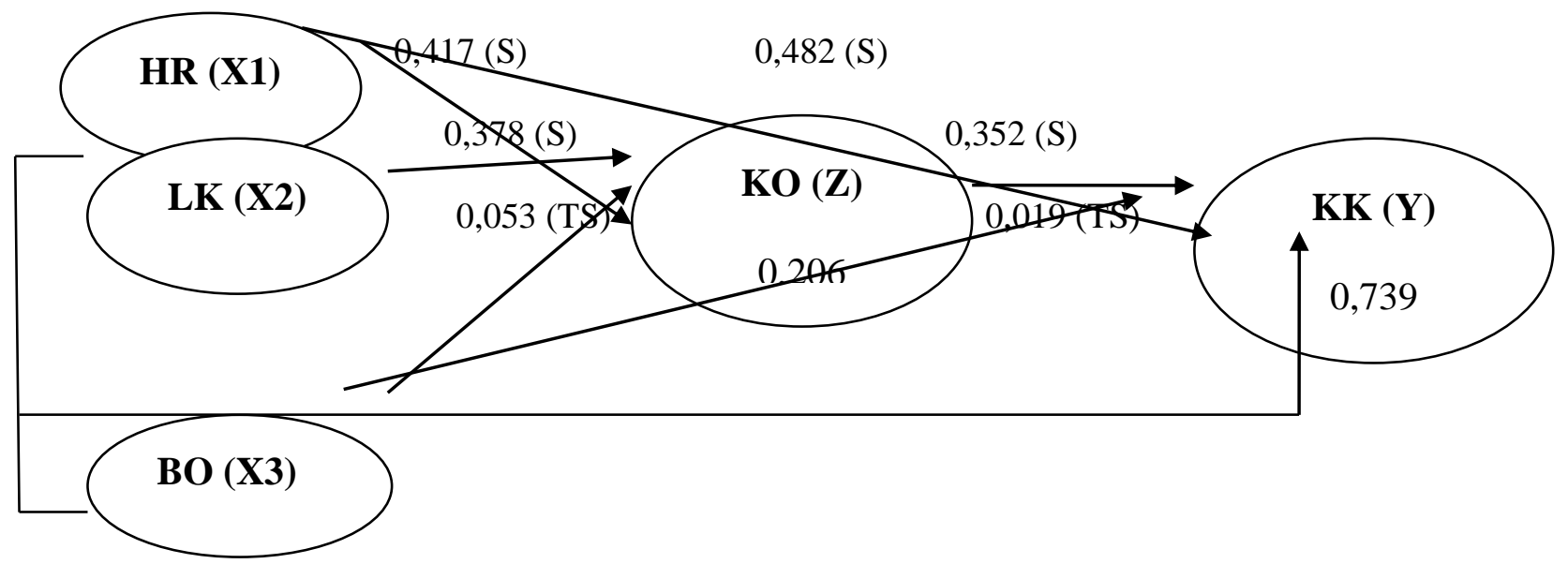

Dengan memperhatikan koefisien pada masing masing pengaruh langsung dari variabel bebas tertentu terhadap variabel terikat dan variabel intervening tersebut. Dapat dibandingkan seberapa baik nilai pengaruh langsung perbedaan individu dan kompetensi terhadap komitmen karyawan dibanding nilai pengaruh tidak langsung melalui variable efektivitas kepemimpinan sebagai intervening. Berikut masing-masing pembahasan untuk hipotesis :

a) Pengaruh Human Relation terhadap komitmen karyawan melalui Kinerja Karyawan

Penilaian hipotesis ini akan, membandingkan mana yang lebih baik antara pengaruh langsung yaitu pengaruh Human Relation terhadap Kinerja Karyawan dengan pengaruh tidak langsung Human Relation terhadap Kinerja Karyawan melalui Komitmen Organisasi. Berikut informasi dari ketiga pengaruh langsung pada Table 6 :

Tabel 6

Perbandingan Nilai Pengaruh langsung dengan pengaruh tidak langsung pengaruh Human Relation terhadap Kinerja Karyawan melalui Komitmen Organisasi

\begin{tabular}{lcrccc}
\hline \multicolumn{2}{c}{ Uraian } & & $\begin{array}{c}\text { Pengaruh } \\
\text { langsung } \\
\text { (dirrect effect) }\end{array}$ & $\begin{array}{c}\text { Pengaruh tidak } \\
\text { langsung } \\
\text { (inderect effect) }\end{array}$ & Total effect \\
\hline $\begin{array}{l}\text { Pengaruh human } \\
\text { kinerja karyawan }\end{array}$ & $\begin{array}{c}\text { relation } \\
\text { melalui }\end{array}$ & $\begin{array}{r}\text { terhadap } \\
\text { komitmen }\end{array}$ & $\begin{array}{c}0,232 \\
(0,482 \times 0,482)\end{array}$ & $\begin{array}{c}0,146 \\
(0,417 \times 0,352)\end{array}$ & 0,378 \\
\hline
\end{tabular}
organisasi

Sumber:lampiran hasil pengolahan datatahun 2019

Berdasarkan temuan hasil perbandingan di atas,dapat di analisis nilai pengaruh tidak langsung(indirect effect)Pengaruh Human Relationterhadap Kinerja Karyawan melalui Komitmen Organisasi. jika variableHuman Relation secara langsung mempengaruhi Kinerja Karyawan. Maka nilai koefisien estimasi yang di peroleh adalah sebanyak 0,232, sedangkan jika melalui pengaruh tidak langsung atau pengaruh Human Relation terhadap Kinerja Karyawan melalui Komitmen Organisasi, 
maka tambahan nilai koefisien estimasi diperoleh sebesar 0,146. Dengandemikian total effect dari hipotesis ini adalah sebesar 0,378 yaitu pengaruh langsung di tambah pengaruh tidak langsung melalui variable intervening atau0,232+0,146=0,378.

Maka dapat disimpulkan bahwa nilai pengaruh tidak langsung lebih kecil dari nilai pengaruh langsung melalui variable intervening atau $0,232>0,146$.

Artinya hubungan tidak langsung lebih kecil nilainya dari hubungan langsung, yang berarti Komitmen Organisasi tidak memediasi hubungan antara Human Relation terhadap Kinerja Karyawan.

\section{Tabel 7}

Perbandingan Nilai Pengaruh langsung dengan pengaruh tidak langsung pengaruh Lingkungan Kerja terhadap Kinerja Karyawan melalui Komitmen Organisasi

\begin{tabular}{lcccc}
\hline \multicolumn{1}{c}{ Uraian } & $\begin{array}{c}\text { Pengaruh } \\
\text { langsung } \\
\text { (dirrect effect) }\end{array}$ & $\begin{array}{c}\text { Pengaruh tidak } \\
\text { langsung } \\
\text { (inderect effect) }\end{array}$ & Total effect \\
\hline $\begin{array}{l}\text { Pengaruh Lingkungan Kerja } \\
\text { terhadap kinerja karyawan melalui } \\
\text { komitmen organisasi }\end{array}$ & $\begin{array}{c}0,025 \\
(0,159 \times 0,159)\end{array}$ & $\begin{array}{c}0,133 \\
(0,4378 \times 0,352)\end{array}$ & 0,158 \\
\hline
\end{tabular}

Sumber:Lampiran Hasil Pengolahan Data.Tahun 2019

Berdasarkan temuan hasil perbandingan di atas,dapat di analisis nilai pengaruh tidak langsung(indirect effect)Pengaruh Lingkungan Kerja terhadap Kinerja Karyawan melalui Komitmen Organisasi. jika variable Lingkungan Kerja secara langsung mempengaruhi Kinerja Karyawan. Maka nilai koefisien estimasi yang di peroleh adalah sebanyak 0,025,sedangkan jika melalui pengaruh tidak langsung atau pengaruh Lingkungan Kerja terhadap Kinerja Karyawan melalui Komitmen Organisasi, maka tambahan nilai koefisien estimasi diperoleh sebesar 0,133. Dengandemikian total effect dari hipotesis ini adalah sebesar 0,158 yaitu pengaruh langsung di tambah pengaruh tidak langsung melalui variable intervening atau $0,025+0,133=0,158$.

Maka dapat disimpulkan bahwa nilai pengaruh tidak langsung lebih besar dari nilai pengaruh langsung melalui variable intervening atau $0,025<0,133$.

Artinya hubungan tidak langsung lebih besar nilainya dari hubungan langsung, yang berarti Komitmen Organisasi memediasi hubungan antara Lingkungan Kerjaterhadap Kinerja Karyawan.

Tabel 8

Perbandingan Nilai Pengaruh langsung dengan pengaruh tidak langsung pengaruh Budaya Organisasi terhadap Kinerja Karyawan melalui Komitmen Organisasi

\begin{tabular}{|l|c|c|c|}
\hline \multicolumn{1}{|c|}{ Uraian } & $\begin{array}{c}\text { Pengaruh } \\
\text { langsung } \\
\text { (dirrect effect) }\end{array}$ & $\begin{array}{c}\text { Pengaruh tidak } \\
\text { langsung (inderect } \\
\text { effect) }\end{array}$ & Total effect \\
\hline $\begin{array}{l}\text { Pengaruh Budaya Organisasi terhadap } \\
\text { kinerja karyawan melalui komitmen } \\
\text { organisasi }\end{array}$ & $\begin{array}{c}0,00036 \\
(0,019 x 0,019)\end{array}$ & $\begin{array}{c}0,018 \\
(0,053 \times 0,352)\end{array}$ & 0,01836 \\
\hline
\end{tabular}

Sumber:Lampiran Hasil Pengolahan DataTahun 2019

Berdasarkan temuan hasil perbandingan di atas,dapat di analisis nilai pengaruh tidak langsung(indirect effect)Pengaruh Budaya Organisasiterhadap Kinerja Karyawan melalui Komitmen Organisasi. jika variableBudaya Organisasi secara langsung mempengaruhi Kinerja Karyawan. Maka nilai koefisien estimasi yang di peroleh adalah sebanyak 0,00036, sedangkan jika melalui pengaruh tidak langsung atau pengaruh Budaya Organisasi terhadap Kinerja Karyawan melalui Komitmen Organisasi, maka tambahan nilai koefisien estimasi diperoleh sebesar 0,018. Dengandemikian total effect dari hipotesis ini adalah sebesar 0,01836yaitu pengaruh langsung di tambah pengaruh tidak langsung melalui variable intervening atau 0,00036+0,018=0,01836.

Maka dapat disimpulkan bahwa nilai pengaruh tidak langsung lebih besar dari nilai pengaruh langsung melalui variable intervening atau 0,00036<0,018. 
Artinya hubungan tidak langsung lebih besar nilainya dari hubungan langsung, yang berarti Komitmen Organisasi memediasi hubungan antara Budaya Organisasiterhadap Kinerja Karyawan.

\section{Kesimpulan}

Dari Berdasarkan hasil penelitian yang telah dilakukan, maka penulis dapat mengimplikasikan hal-hal sebagai berikut:

1. Terdapat pengaruh Positif dan signifikan Human relation terhadap komitmen organisasi pada Dinas Pendidikan Provinsi Sumatera Barat. Dimana tingkat signifikan lebih kecil dari dari alpha $(0,013<0,05)$. Dengan demikian $\mathrm{Ho}$ Tolak dan $\mathrm{H}_{1}$ diterima yang berarti dapat disimpulkan Human relation berpengaruh positif signifikan terhadap komitmen organisasi pada Dinas Pendidikan Provinsi Sumatera Barat. Semakin baik Human relation yang diberikan maka semakin tinggi tingkat komitmen.

2. Terdapat pengaruh positif dan signifikan Lingkungan kerja terhadap komitmen organisasi pada Dinas Pendidikan Provinsi Sumatera Barat. Dimana tingkat signifikan lebih kecil dari alpha $(0,001<0,05)$. Dengan demikian $\mathrm{Ho}$ Tolak dan $\mathrm{H}_{2}$ diterima yang berarti dapat disimpulkan Lingkungan kerja berpengaruh positif signifikan terhadap komitmen organisasi pada Dinas Pendidikan Provinsi Sumatera Barat, semakin terjangkaunya Lingkungan kerja yang diberikan maka semakin tinggi pula komitmen organisasinya.

3. Terdapat pengaruh positif dan signifikan budaya organisasi terhadap komitmen organisasi pada Dinas Pendidikan Provinsi Sumatera Barat. Dimana tingkat signifikan lebih besar dari alpha $(0,676>0,05)$. Dengan demikian Ho diterima dan $\mathrm{H}_{\mathrm{a}}$ ditolak yang berarti dapat disimpulkan budaya organisasi berpengaruh positif signifikan terhadap komitmen organisasi pada Dinas Pendidikan Provinsi Sumatera Barat, semakin terjangkaunya budaya organisasi yang diberikan maka semakin tinggi pula komitmen organisasinya. Semakin baik lingkungan kerja akan menimbulkan kepuasan dalam diri karyawan sehingga kinerja karyawan akan meningkat. Faktor terkuat kedua adalah kepemimpinan. Semakin baik kepemimpinan maka karyawan akan mucul rasa puas kemudian timbul rasa komiten sehingga kinerja karyawan meningkat. Pada pengujian ini diperoleh hasil budaya organisasi berpengaruh positif dan tidak signifikan terhadap kinerja organisasi. Budaya yang baik di perusahaan akan menimbulkan rasa puas dan komitmen yang tinggi tapi tidak berpengaruh terhadap kinerja karyawan.

4. Terdapat pengaruh positif dan signifikan Human relation terhadap Kinerja pada Dinas Pendidikan Provinsi Sumatera Barat. Dimana tingkat signifikan lebih kecil dari dari alpha $(0,00<0,05)$. Dengan demikian Ho Tolak dan $\mathrm{H}_{4}$ diterima yang berarti dapat disimpulkan Human relation berpengaruh positif signifikan terhadap Kinerja pada Dinas Pendidikan Provinsi Sumatera Barat. Semakin baik Human relation maka semakin meningkat Kinerja.

5. Terdapat pengaruh positif dan tidak signifikan Lingkungan kerja terhadap Kinerja pada Dinas Pendidikan Provinsi Sumatera Barat. Dimana tingkat signifikan lebih kecil dari dari alpha $(0,004<0,05)$. Dengan demikian н5 Terima dan но diterima yang berarti dapat disimpulkan Lingkungan kerja berpengaruh positif signifikan terhadap Kinerja pada Dinas Pendidikan Provinsi Sumatera Barat. Semakin baik Lingkungan kerja maka semakin meningkat Kinerja.

6. Terdapat pengaruh positif dan signifikan Budaya Organisasi terhadap Kinerja pada Dinas Pendidikan Provinsi Sumatera Barat. Dimana tingkat signifikan lebih besar dari dari alpha $(0,735>0,05)$. Dengan demikian Ho Tolak dan $\mathrm{H}_{7}$ ditolak yang berarti dapat disimpulkan Budaya Organisasi berpengaruh positif signifikan terhadap Kinerja pada Dinas Pendidikan Provinsi Sumatera Barat. Semakin tinggi budaya organisasi maka semakin menunjukan kinerja karyawan. 


\section{DAFTAR PUSTAKA}

Basuki, A. T. dan, \& Prawoto, N. (2016). Analisis Regresi Dalam Penelitian Ekonomi \& Bisnis: Dilengkapi Aplikasi SPSS \& EVIEWS. In PT Rajagrafindo Persada.

Dr. Kasmir M.M., M. . (2016). Manajemen Sumber Daya Manusia (Teori dan Praktik). In Manajemen Sumber Daya Manusia (Teori dan Praktik).

Effendy, O. U. (2011). Ilmu Komunikasi: Teori dan Prakteknya. Bandung : Remaja Rosdakarya.

Luthans, F. (2012). Prilaku Organisasi. Yogyakarta: Penerbit Andi.

Mayangsari, S. (2017). Analisis pengaruh kompensasi, Motivasi, Lingkungan kerja terhadap kinerja karyawan dengan komitmen organisasi sebagai variabel intervening pada, PT Bara Permata Wining. Jurnal Informasi, Perpajakan, Akuntansi Dan Keuangan, Vol 12, No.07

Riduwan, \& Sunarto. (2017). Pengantar Statistika untuk Penelitian: Pendidikan, Sosial, Komunikasi, Ekonomi dan Bisnis. In Bandung.

Robins, stephen. p. (2014). Teori Budaya Organisasi. In perilaku organisasi.

sugiyono. (2014). Metode penelitian. Metode Penelitian.

Sugiyono. (2016. metode penelitian kuantitatif dan kualitatif. R\&D, CV. Alfabeta

Supriatna. (2017). Pengaruh Human Relation (Hubungan Antar Manusia) Dan Lingkungan Kerja Non Fisik Terhadap Kinerja Karyawan Dengan Komitmen Organisasi Pegawai Sebagai Variabael Intervening Pd. Bank Perkreditan Rakyat Kota Bandung. Scientific Journals, Vol 6, No.

SuryaniBudiono, D. (2016). Pengaruh Budaya Organisasi Terhadap Kinerja Karyawan Melalui Komitmen Organisasi Sebagai Variabel Intervening Pada Pt. Kerta Rajasa Raya. Journal of Research In Economics and MAN, Volume 16, Halaman 29-4.

Wibowo. (2014). Menejemen Kinerja. PT. Rajagrafindo Persada, Depok. 